\title{
Radiocarbon chronology of the Neolithic in the Povolzhye (Russian Eastern Europe)
}

\author{
Alexander Vybornov ${ }^{1}$, Marianna Kulkova ${ }^{2}$, Konstantin Andreev ${ }^{1}$ and Eugeny Nesterov ${ }^{2}$ \\ 1 Samara State University of Social Sciences and Education, Samara, RU \\ vibornov_kin@mail.ru \\ 2 Russian State Pedagogical University, Sankt-Peterburg, RU
}

\begin{abstract}
The radiocarbon dates obtained on materials from archaeological sites of the Low and Middle Povolzhye are presented in this article. The analysis of the complex of radiocarbon dates allowed a determination of the most appropriate dates for forming chronological schemes of cultural development in this region. The chronological frameworks of the Early Neolithic in the Low Povolzhye were determined from 6600-5500 cal BC; in the Middle Povolzhye they are from 6500 to $4600 \mathrm{cal} \mathrm{BC}$.
\end{abstract}

KEY WORDS - Neolithic; Lower Volga region; Forest-steppe Volga region; reservoir effect; absolute chronology

\section{Radiokarbonska kronologija neolitika v porečju reke Volge (vzhodni del ruske Evrope)}

\begin{abstract}
IZVLEČEK - V članku predstavljamo rezultate radiokarbonskih datacij zbirov iz arheoloških najdišč na območju spodnje in srednje Volge. Z analizo kompleksnih radiokarbonskih datumov smo lahko določili tiste datume, ki so najbolj ustrezni za oblikovanje časovnega okvirja kulturnega razvoja $v$ regiji. V spodnjem toku reke Volge ga postavljamo v čas med 6600 in 5500 pr. n. št., na območju srednjega toka reke Volge pa med 6500 in 4600 pr. n. št.
\end{abstract}

KLJUČNE BESEDE - neolitik; spodnji tok reke Volge; območje gozdne stepe; efekt rezervoarja; absolutna kronologija

\section{Introduction}

Povolzhye is located in the Volga River basin. In the south, this region borders the Caucasus and Middle Asia, the Don River basin in the west, the Urals region in the east, and the Kama region in the north (Fig. 1). The Povolzhye region has an important meaning for investigations, because during the Neolithic period strong cultural interconnections between people from these regions were established. Thus, the chronology of these cultures has a priority aspect for the study of Neolithisation of Eastern Europe. Russian archaeologists consider the Neolithic of Eastern Europe as the period when pottery appeared. The main problem of radiocarbon dating sites in the steppe and forest-steppe zone is the lack of the necessary quantities of organic material for dating, which has not been preserved in the cultural layers. Until 2007, there were less than 20 radiocarbon dates for the numerous archaeological sites of this region, most of which were doubtful. Therefore the radiocarbon dating of organics from pottery was used, as well as dating of other organic materials (charcoal, bone, charred crusts). In the last ten years, $290 \mathrm{ra}$ diocarbon dates have been obtained: 70 for the Northern Caspian region; 41 for the Low Volga River region; 89 for the forest-steppe of the Middle Volga region; 31 for the Sura region; 34 for the Pri- 
Fig. 1. Map of the Povolzhye region: 1 Kairshak III; 2 Baibek; 3 Tenteksor; 4 Kugat IV; $5 \mathrm{Ku}$ lagaysi; 6 Jangar; 7 TuBuzgu-Huduk; 8 Orlovka; 9 Varfolomeevskaya; 10 Algay; 11 Ivanovskaya; 12 Vilovatovskaya; 13 Chekalino IV; 14 B. Rakovka II; 15 Kalmykovka I; 16 Krasniy Gorodok I; 17 Niznaya Orlyanka II; 18 Krasniy Yar; 19 Vjunovo lake I; 20 Utuzh I; 21 Imerka VII; 22 II Sherbetskaya; 23 Dubovskaya III.

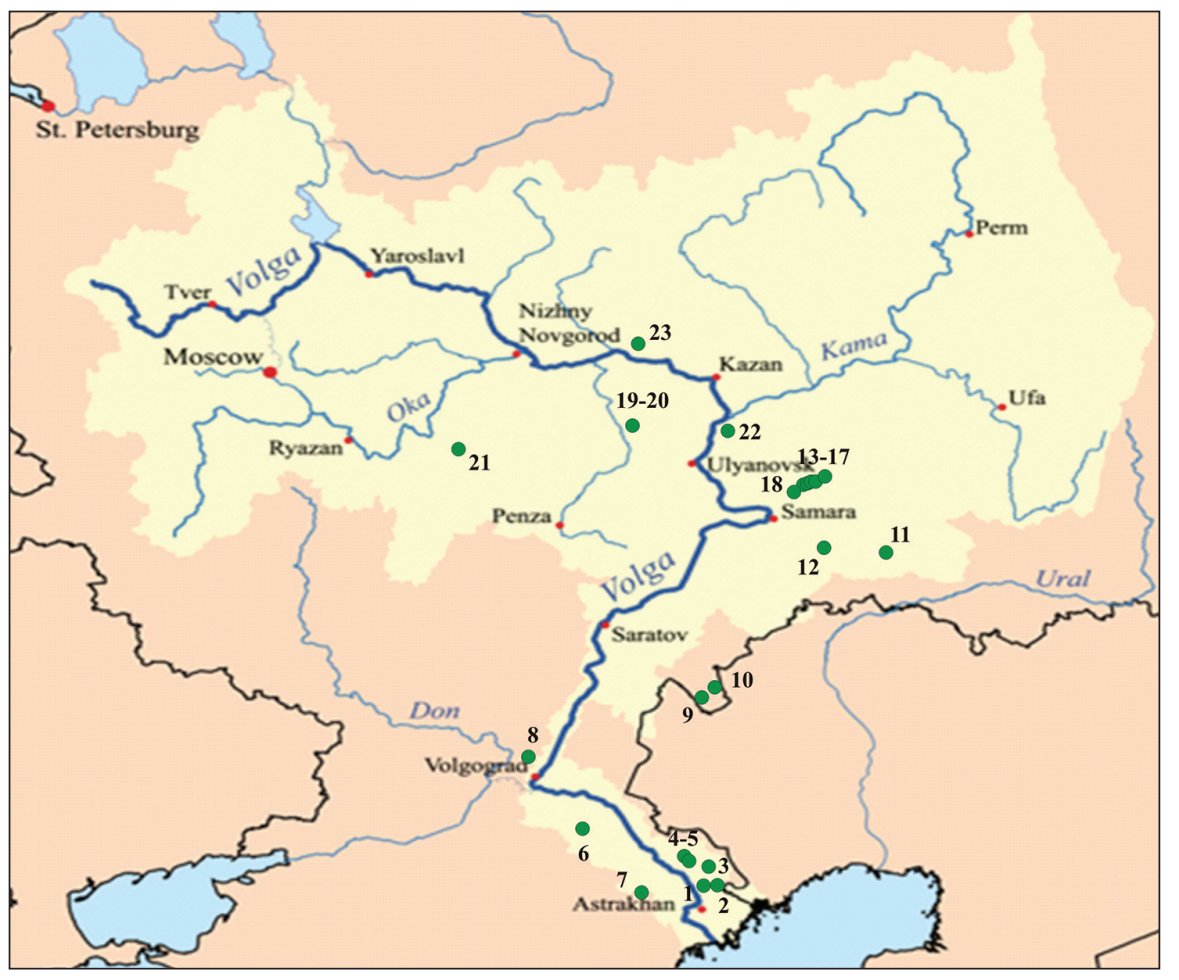

mokshanie, and 24 for the forest zone of the Middle Volga region. This complex of radiocarbon dates allows us to establish the validity of dates obtained, especially the acceptability of dates on the organics from pottery and to determine the chronological frameworks of Neolithic cultures in the Povolzhye. The dates presented in the Table 1 were obtained for the most significance and etalon sites. They are representative for these sites and have coincidence on the base of different organic materials. The dates which did not been included in the Table 1 were published elsewhere earlier.

\section{Neolithic cultures of the Povolzhye region}

The detailed characteristics of artefacts, cultures and cultural types of Neolithic complexes of Povolzhye have been presented in numerous publications $(e . g$., Mamonov 2000.147-176; Morgunova 2004.214216; Vybornov 2008; Vybornov et al. 2009a.7180; 2009b.81-88; Grechkina et al. 2014. 79-90; Andreev 2015.1-16; Andreev et al. 2016a.130-139; Yudin et al. 2016.61-68).

\section{The Northern Caspian region}

In Figure 1 we present the sites where the Kairshak pottery type dated to $c$. $7^{\text {th }}$ millennium $\mathrm{BC}$ was found in the semi-desert northern coast of the Caspian Sea (Fig. 1), This type of pottery is archaic in style. The flat-bottomed vessels were made of organic-rich silt and have geometric ornamentation. The stone indu- stry is closely analogous to the local Mesolithic stone industry, which is characterised by artefacts such as geometric microliths in the form of segments and parallelograms. These features of material culture are evidence of the local origin of this Neolithic culture (Kozin 2002.1-16).

In the north-western part of the Caspian Sea coast, the earliest sites of the earliest stage of Jangar type (Tubuzgukhuduk site) (Fig. 1.site 7) date to the first

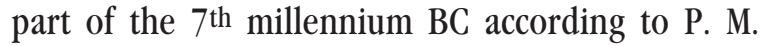
Koltsov (Koltsov 2005). According to the features of the flint tools and some pottery characteristics, the Neolithisation of this territory began from the Caucasus; for example, the arrowheads and trapezes of the north-western Caspian Sea and the Caucasus are similar (Koltsov 2005). At the same time, some innovations were linked to local populations. The main innovation was the appearance of pottery-making traditions. In the middle of the $7^{\text {th }}$ millennium BC, the populations which produced the Kairshak type migrated from the northern Caspian Sea region towards the steppe region of the Volga River basin and the north-western coast of the Caspian. This process was probably triggered by paleoclimatic changes. The bearers of the Kairshak and Jangar cultures influenced the formation of the Orlovskaya culture in the lower part of the Volga basin (Varfolomeevskaya site) (Fig. 1.site 9). Three cultural layers were identified at the Varfolomeevskaya site: lower (3), middle (2), and upper layer (1). Microliths (such as 


\begin{tabular}{|c|c|c|c|c|c|c|}
\hline No. & Site & 14CAge (BP) & Age, cal BC ( $2 \sigma)$ & $\delta 13 C$ (\%०) & Lab index & Material \\
\hline 1 & Kairshak III & $7775 \pm 42$ & $6690-6490$ & $-28,7$ & Ua-41359 & Food crusts \\
\hline 2 & Kairshak III & $7700 \pm 100$ & $6830-6370$ & $n / d$ & SPb_377 & Food crusts \\
\hline 3 & Kairshak III & $7300 \pm 100$ & $6505-5746$ & $n / d$ & SPb_422 & Pottery \\
\hline 4 & Kairshak III & $7190 \pm 80$ & $6230-5890$ & $n / d$ & Ki-14633 & Animal bone \\
\hline 5 & Kairshak III & $7870 \pm 100$ & $7050-6500$ & $n / d$ & Ki-16401 & $\begin{array}{l}\text { Carbonates from } \\
\text { pottery }\end{array}$ \\
\hline 6 & Kairshak III & $7290 \pm 190$ & $6500-5750$ & $n / d$ & Ki-1600 & $\begin{array}{l}\text { Organics from } \\
\text { pottery }\end{array}$ \\
\hline 7 & Baibek & $7937 \pm 48$ & $7037-6684$ & $-29,3$ & Ua-50262 & Food crusts \\
\hline 8 & Baibek & $6827 \pm 100$ & $5917-5604$ & $\mathrm{n} / \mathrm{d}$ & SPb-1712 & Charcoal \\
\hline 9 & Baibek & $7350 \pm 50$ & $6373-6070$ & $n / d$ & Poz-57060 & Food crusts \\
\hline 10 & Baibek & $6955 \pm 80$ & $6002-5708$ & $\mathrm{n} / \mathrm{d}$ & SPb-1709 & Animal bone \\
\hline 11 & Baibek & $6948 \pm 120$ & $6034-5634$ & $\mathrm{n} / \mathrm{d}$ & SPb-1713 & Charcoal \\
\hline$\overline{12}$ & Baibek & $6986 \pm 44$ & $5983-5759$ & -10 & Ua-5026o & Charcoal \\
\hline 13 & Baibek & $6925 \pm 120$ & $6021-5626$ & $n / d$ & SPb-1716 & Pottery \\
\hline 14 & Tenteksor & $6695 \pm 40$ & $5680-5530$ & $-27,7$ & Ua-35277 & Food crusts \\
\hline 15 & Tenteksor & $6540 \pm 100$ & $5640-5310$ & $n / d$ & SPb-315a & Animal bone \\
\hline 16 & Tenteksor & $6640 \pm 80$ & $5720-5470$ & $\mathrm{n} / \mathrm{d}$ & Ki-14101 & Pottery \\
\hline 17 & Tenteksor & $6650 \pm 100$ & $5740-5460$ & $n / d$ & SPb-423 & Pottery \\
\hline 18 & Kugat IV & $7680 \pm 100$ & $6690-6380$ & $n / d$ & Ki-14501 & Pottery \\
\hline 19 & Kugat IV & $7560 \pm 90$ & $6600-6220$ & $\mathrm{n} / \mathrm{d}$ & Ki-14500 & Pottery \\
\hline 20 & Kulagaysi & $7380 \pm 120$ & $6450-6027$ & $n / d$ & SPb-1725 & Pottery \\
\hline 21 & Jangar layer 3 & $7080 \pm 90$ & $6090-5710$ & $n / d$ & Ki-14639 & Pottery \\
\hline 22 & Jangar layer 3 & $6990 \pm 90$ & $6030-5710$ & $\mathrm{n} / \mathrm{d}$ & Ki-14640 & Pottery \\
\hline 23 & Jangar layer 2-3 & $6870 \pm 130$ & $6010-5550$ & $n / d$ & IGAN-2819 & Charcoal \\
\hline 24 & Jangar 2 & $6100 \pm 70$ & $5220-4840$ & $n / d$ & Le- 2564 & Charcoal \\
\hline 25 & Jangar 2 & $6780 \pm 90$ & $5840-5510$ & $\mathrm{n} / \mathrm{d}$ & Ki-14641 & Pottery \\
\hline 26 & Jangar 1 & $5890 \pm 70$ & $4940-4580$ & $\mathrm{n} / \mathrm{d}$ & Le-2901 & Charcoal \\
\hline 27 & Jangar 1 & $6564 \pm 44$ & $5575-5470$ & $-27,5$ & Hela-3255 & Crust \\
\hline 28 & Varfolomeevskaya 3 layer & $6980 \pm 200$ & $6250-5500$ & $\mathrm{n} / \mathrm{d}$ & $\operatorname{Gin} 6546$ & Charcoal \\
\hline 29 & Varfolomeevskaya 3 layer & $7250 \pm 80$ & $6250-5980$ & $n / d$ & Ki-14109 & Pottery \\
\hline 30 & Algay & $7284 \pm 80$ & $6271-6008$ & $\mathrm{n} / \mathrm{d}$ & SPb-2144 & Humid acids \\
\hline 31 & Varfolomeevskaya 2 b layer & $7100 \pm 110$ & $6220-5740$ & $\mathrm{n} / \mathrm{d}$ & SPb-941 & Food crusts \\
\hline 32 & Varfolomeevskaya 2B layer & $7034 \pm 41$ & $6010-5830$ & $-28,0$ & Ua-4136o & Food crusts \\
\hline 33 & Varfolomeevskaya 2 B layer & $6850 \pm 40$ & $5816-5659$ & $\mathrm{n} / \mathrm{d}$ & Poz-52697 & Food crusts \\
\hline 34 & Algay & $6800 \pm 40$ & $5741-5631$ & $n / d$ & Poz- 65198 & Food crusts \\
\hline 35 & Algay & $6820 \pm 80$ & $5889-5614$ & $n / d$ & SPb-1510 & Animal bone \\
\hline 36 & Algay & $6577 \pm 80$ & $5641-5374$ & $\mathrm{n} / \mathrm{d}$ & SPb-1478 & Animal bone \\
\hline 37 & Orlovka & $6647 \pm 150$ & $5846-5315$ & $\mathrm{n} / \mathrm{d}$ & SPb-1727 & Pottery \\
\hline 38 & Varfolomeevskaya 2A layer & $6544 \pm 38$ & $5620-5580$ & $-25,1$ & Ua-41361 & Food crusts \\
\hline 39 & Algay & $6490 \pm 40$ & $5527-5367$ & $\mathrm{n} / \mathrm{d}$ & Poz-76004 & Charcoal \\
\hline 40 & Varfolomeevskaya 2A layer & $6363 \pm 150$ & $5650-4950$ & $n / d$ & SPb-937 & Food crusts \\
\hline 41 & Varfolomeevskaya (upper) & $5800 \pm 150$ & $5050-4300$ & $n / d$ & SPb-939 & Crust \\
\hline 42 & Algay & $5875 \pm 60$ & $4856-4580$ & $n / d$ & SPb-1968 & Animal bone \\
\hline$\overline{43}$ & Varfolomeevskaya & $5870 \pm 90$ & $4950-4490$ & $n / d$ & Ki-14614 & Pottery \\
\hline 44 & Ivanovskaya & $7680 \pm 90$ & $6733-6374$ & $n / d$ & Ki-14567 & Pottery \\
\hline 45 & Chekalino IV & $7660 \pm 200$ & $7047-6202$ & $n / d$ & SPb-424 & Pottery \\
\hline 46 & B. Rakovka II & $7613 \pm 120$ & $6750-6200$ & $\mathrm{n} / \mathrm{d}$ & SPb-1733 & Pottery \\
\hline 47 & Ivanovskaya & $7560 \pm 70$ & $6566-6248$ & $\mathrm{n} / \mathrm{d}$ & SPb-587 & Pottery \\
\hline 48 & Chekalino IV & $7250 \pm 60$ & $6229-6016$ & $n / d$ & Poz-42051 & $\begin{array}{l}\text { Carbon from } \\
\text { Pottery }\end{array}$ \\
\hline 49 & Chekalino IV & $7127 \pm 150$ & $6400-5700$ & $n / d$ & SPb-1731 & Pottery \\
\hline 50 & Vjunovo lake I & $7222 \pm 58$ & $6220-6004$ & -27 & AA-96017.1 & Pottery \\
\hline 51 & Vjunovo lake I & $7160 \pm 40$ & $6092-5927$ & $n / d$ & Poz- 47870 & Pottery \\
\hline
\end{tabular}

Tab. 1. Radiocarbon dates for Neolithic sites in the Povolzhye region. 


\begin{tabular}{|c|c|c|c|c|c|c|}
\hline No. & Site & 14CAge (BP) & Age, cal BC (2 б) & $\delta 13 C$ (\%०) & Lab index & Material \\
\hline 52 & Imerka VII & $7205 \pm 60$ & $6220-5980$ & $-28,4$ & Hela-3521 & Food crusts \\
\hline 53 & Krasniy Yar & $6700 \pm 70$ & $5730-5490$ & $\mathrm{n} / \mathrm{d}$ & SPb-755 & Food crusts \\
\hline 54 & Kalmykovka I & $6643 \pm 110$ & $5740-5370$ & $n / d$ & SPb-1415 & Pottery \\
\hline 55 & Utuzh I & $6568 \pm 49$ & $5620-5470$ & $n / d$ & Ua-44377 & Food crusts \\
\hline 56 & Utuzh I & $6500 \pm 100$ & $5640-5290$ & $n / d$ & SPb-834 & Pottery \\
\hline 57 & Dubovskaya III & $7000 \pm 150$ & $6250-5600$ & $n / d$ & SPb-1290 & Pottery \\
\hline 58 & Dubovskaya III & $6892 \pm 40$ & $5890-5700$ & $-28,1$ & Ua-44724 & Food crusts \\
\hline 59 & II Sherbetskaya & $6620 \pm 90$ & $5720-5460$ & - & Ki-14134 & Pottery \\
\hline 60 & Imerka VII & $6546 \pm 60$ & - & $n / d$ & Hela-3253 & Food crusts \\
\hline 61 & Vilovatovskaya & $6320 \pm 90$ & $5476-5061$ & $n / d$ & Ki-14090 & pottery \\
\hline 62 & Vilovatovskaya & $6160 \pm 100$ & $5322-4842$ & $n / d$ & Ki-14088 & pottery \\
\hline 63 & Vilovatovskaya & $5960 \pm 80$ & $5056-4618$ & $n / d$ & Ki-14089 & pottery \\
\hline 64 & Kalmykovka I & $5950 \pm 120$ & $5250-4500$ & $n / d$ & SPb-1759 & pottery \\
\hline 65 & Kalmykovka I & $5989 \pm 70$ & $5060-4710$ & $\mathrm{n} / \mathrm{d}$ & SPb-1876 & bone \\
\hline
\end{tabular}

\section{Tab. 1. Continue ...}

geometric microliths and trapezes) similar to the Kairshak type were found in the lower part of the third cultural layer at Varfolomeevskaya. Organic silt (probably from the river floodplain) was the basic raw material used in pottery making. The pottery is flat-bottomed, with pinned and incised ornamentation. In this area, the Kairshak culture contributed to the further development of the Varfolomeevskaya and Jangar traditions. This can be traced in the pottery, ornamentation technique and types of decoration of ceramics.

\section{The Volga River region}

The earliest Neolithic sites on the border between the steppe and forest steppe in the Volga River basin are indicated by complexes of Elshanka-type pottery (Fig. 1). Elshanian culture had two stages, an earlier and later. The most important sites of the early cultural stage are at Ivanovskaya in the Samara River basin and Chekalino in the Sok River basin. The pottery was made of silt clay; the bases are pointed and decoration sparse, with pits and incised lines. The ${ }_{14} \mathrm{C}$ dating of different materials (charred crusts, bones, pottery) confirms the appearance of this pottery as early as the beginning of the $7^{\text {th }}$ millennium BC (Tab. 1). The typology and technological characteristics of the Elshanka pottery type show their nonlocal origin. The closest analogues to this type can be found on the eastern coast of the Caspian and the Central Asian interfluves, at the Uchaschy, Daryasay, and Dzhebel sites (Kholmatova 2012.106-110). Radiocarbon dates on the earliest Neolithic materials in Central Asia are of the same age (Brunet et al. 2012.118-124). Specific geometric microliths are also evidence of Neolithiation. There are several reasons for assuming frequent and diachronic impulses during the Neolithisation process in this region. At the end of the $7^{\text {th }}$ millennium BC, some Elshanka tribes directly influenced the process of pottery making in the north-western Middle Volga region, in the Sura River valley (e.g., Vyunovo Lake I and Utuzh sites) and in the Moksha River basin (the Imerka VII site) (Fig. 1). So, there are numerous Early Neolithic sites in the Middle Volga basin with pottery similar to the Elshanka type. They have common characteristics: methods of vessel moulding; the shape of rims and bases of vessels; near absence of ornamentation; small pressed pits between incised decorations, and ornamental elements and motifs. Elshanka culture existed in the forest-steppes of the Volga and Sura river basins probably until the $6^{\text {th }}$ millennium $\mathrm{BC}$.

New sites have been excavated recently in this region. Their stratigraphy, archaeological finds and radiocarbon dating provide new data for modelling a detailed chronology of the Neolithic cultures in this region.

\section{Methods and materials}

Radiocarbon dating of ancient ceramics is an important research topic both for radiocarbon analysis and for archaeology. Pottery is the most abundant material found during excavations of Neolithic sites in Eastern Europe. The various organic materials used for radiocarbon dating, such as charcoal, bone, wood, or soil, are sometimes not associated with the archaeological context of a settlement or cultural layer. However, the radiocarbon dating of organics from pottery has other problems. Firstly, the pottery can 


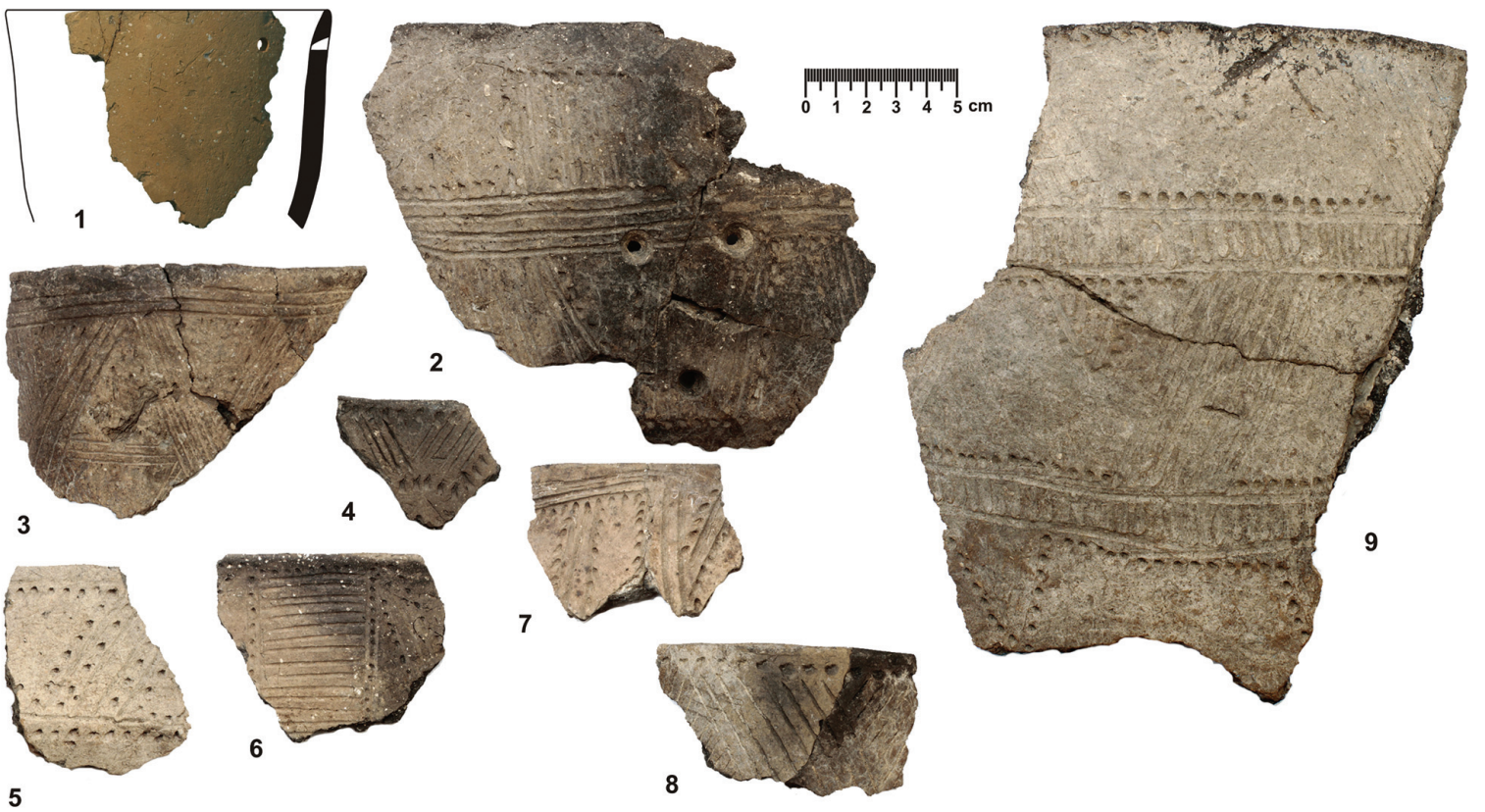

Fig. 2. The Northern Caspian Sea region. Pottery from the Kugat IV (1) and Kairshak III sites (2-9).

be contaminated by younger organics from the soil, such as humic acids, during burial (Stott et al. 2001. 191-197). Sometimes secondary carbonates can be formed inside pottery pores. Older carbonates can be found in the clay composition or as a temper in the form of shell, or carbonate minerals such as calcite or dolomite, and sometimes they cannot be removed by chemical pretreatment (Evin et al. 1989. 276). In other cases, these contaminations can be removed by special chemical pretreatment methods (Hedges et al. 1992.906-915; Anderson et al. 2005. 1-9).
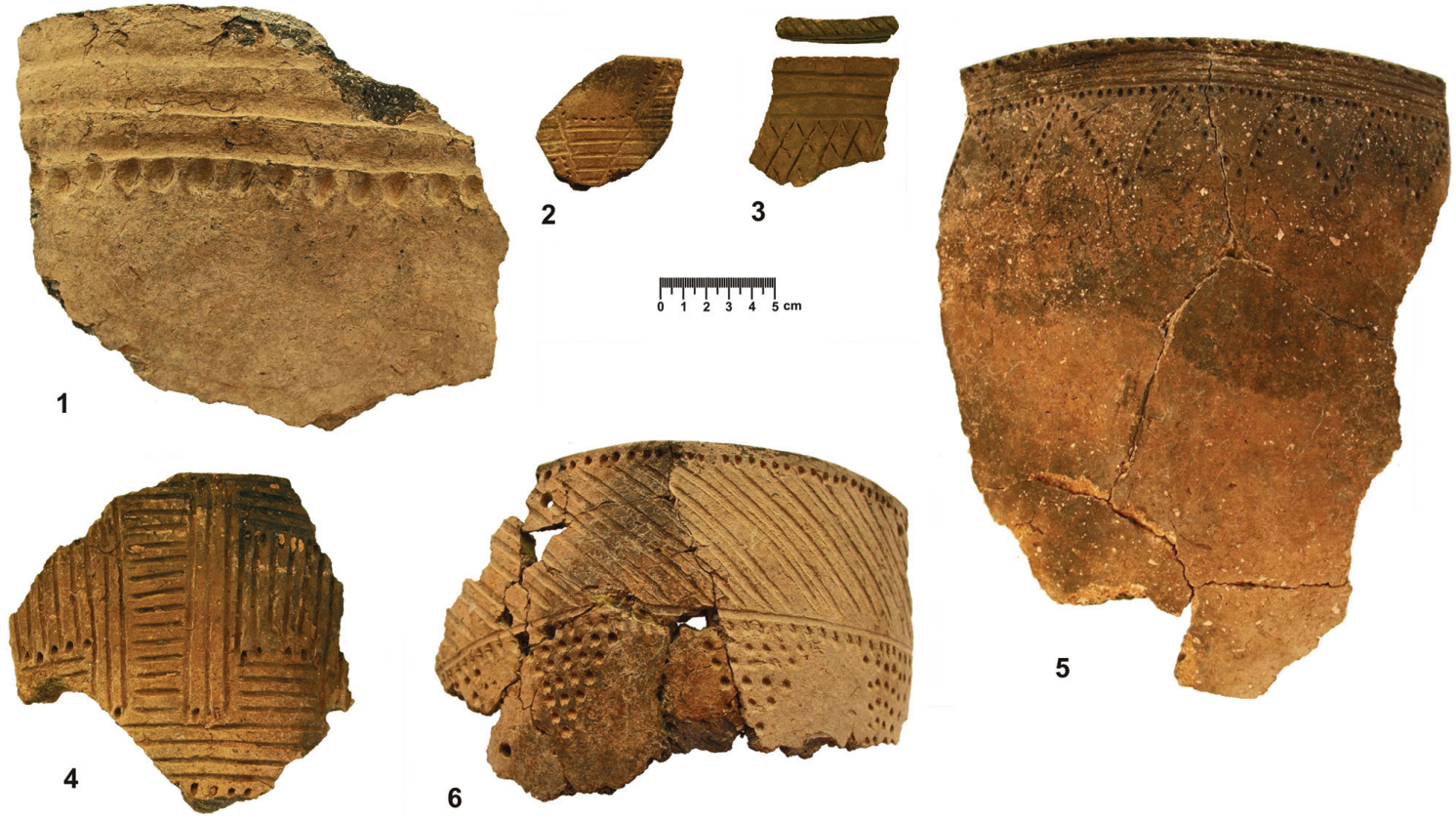
(Hedges et al. 1992.906-915; Delquè Kolic 1995. 275-284; Stott et al. 2001.191-197; Anderson et al. 2005.1-9; Bonsall et al. 2002.47-59). The carbon inside a ceramic sherd whose age is comparable with the time of pottery making or use can be tested after older and younger carbon contaminants have been removed (Kul'kova 2014.115-122). One of the organic residues connected with ancient cooking processes is carbon from charred food crusts on pottery walls (Nakamura et al. 2001.1129-1138). The ra-

Fig. 3. The Northern Caspian Sea region. Pottery from the Baibek site. 
diocarbon dating of charred food crusts gives good results if freshwater, sea fish or seafood were not used during cooking. Otherwise, the reservoir effects lead to older radiocarbon ages of food crusts ( $F i$ scher, Heinemeier 2003.449-466; Boudin et al. 2010.697-705; Kunikita et al. 2013.1334-1340). The measurements of carbon and nitrogen stable isotopes in food crusts may help to determine the type of food in the pottery. Corrections for the reservoir effect on food crust age is done experimentally (Hart et al. 2013.536-552; Philippsen 2013). Another carbon component forming in the pottery during use is soot on the outer walls of vessels. The application of soot for radiocarbon dating has yielded comparable results (Delquè Kolic 1995.275-284). But only AMS dating can be applied for dating this component because of the small amounts of carbon. It should be noted that food crusts or soot are not always found on pottery walls. Sometimes the amounts of food crusts and soot are too little for radiocarbon dating. Therefore, some authors consider radiocarbon dating the organic material from the core of the sherd (Hedges et al. 1992.905-915; Anderson et al. 2005.1-9; Messili et al. 2013.1391-1402). In this case, there is still the problem of reservoir effects if the pottery was used to cook fish or contents with aquatic organics. In this case, the stable isotope analysis can give additional information about the reservoir effect. In addition, clay with older organic inclusions from ancient deposits could be used for pottery making, and the radiocarbon age of such a sherd would be older than expected. In the most cases, the raw materials extracted for early Neolithic pottery making in Eastern Europe were chosen from sources that were modern to ancient people (Vybornov 2008.490). Early pottery was fired at a temperature of 600 $800^{\circ} \mathrm{C}$. The decomposition of organic components and the formation of coal and soot particles occurs in these conditions. The cores of these sherds are grey or black, depending on the amount of unburned organic material.

Carbon from pottery can therefore correspond to the age of its production and use, or it can be older. Radiocarbon dating experiments on pottery yield inconsistent results (Hedges et al. 1992.905915; Delquè Kolic 1995.275-284). Sometimes radiocarbon dates of pottery carbon do not correspond to radiocarbon dates on other organic materials from the same archaeological sites. Some authors (Messili et al. 2013.1391-1402) consider pottery carbon as suitable material for radiocarbon dating. According to Lamia Messili et al. (2013.1391-1402) the accuracy of pottery ${ }^{14} \mathrm{C}$ dates is a direct function of the temper/clay organic matter ratio: the higher it is, the weaker the influence of the organic matter bound to the clay and the more reliable the ${ }^{14} \mathrm{C}$ dating. Jeanette M. O'Malley et al. (1999.19-24) presented a stepwise heating technique to extract only a temper carbon fraction from the interior and exterior parts of potsherds, and obtained preliminary ${ }^{14} \mathrm{C}$ ages for pottery from the Russian Far East (Nakamura et al. 2001.1129-1138). Stepped-combustion dating of earliest pottery from the Russian Far East is also presented by Yaroslav V. Kuzmin et al. (2001).

Samples were pretreated with diluted $\mathrm{HCl}$ acid (1.2N) and $\mathrm{NaOH}(0.1 \mathrm{~N})$ to remove contaminants such as
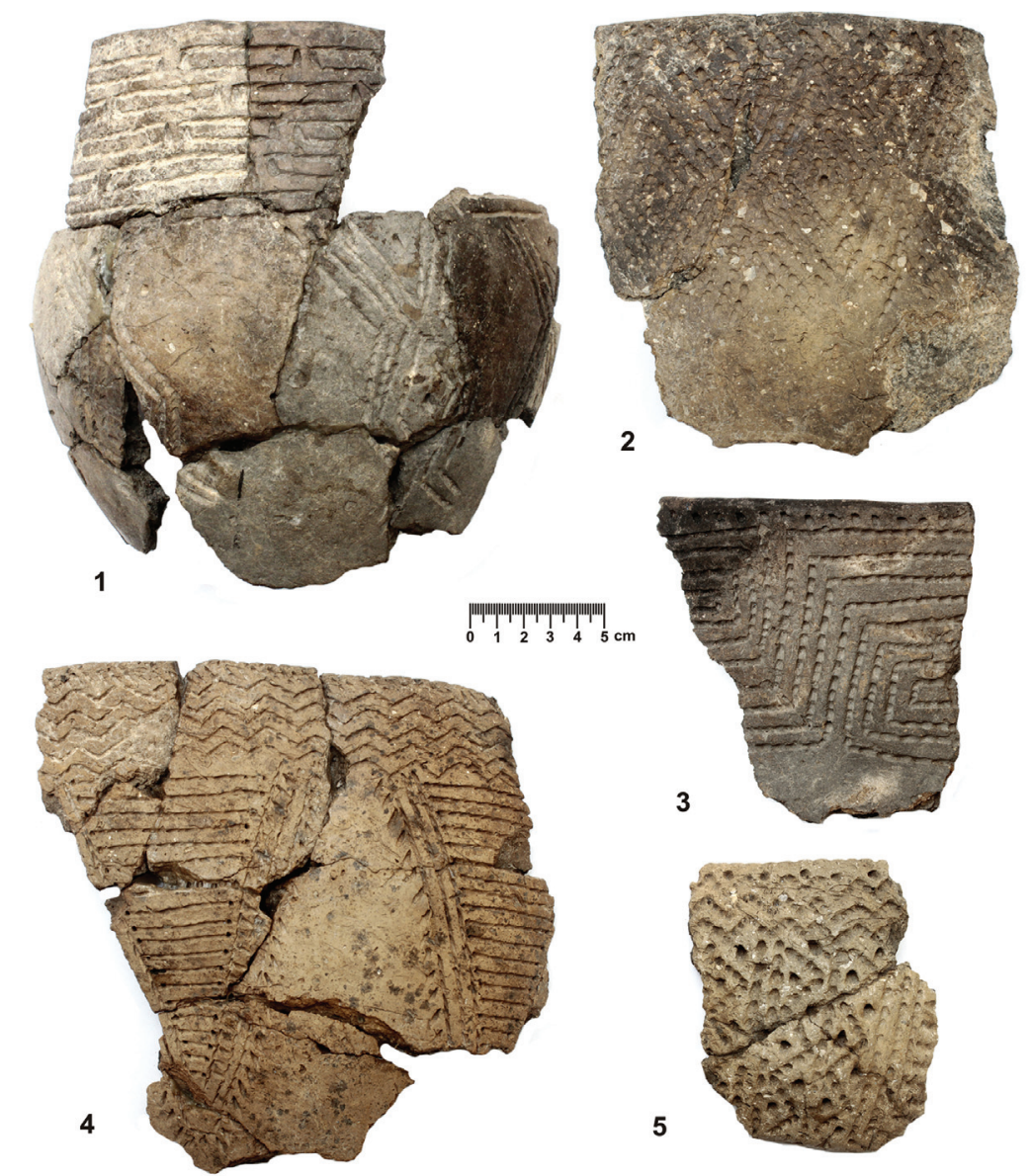

Fig. 4. The Northern Caspian Sea region. Pottery from the Tenteksor site. 

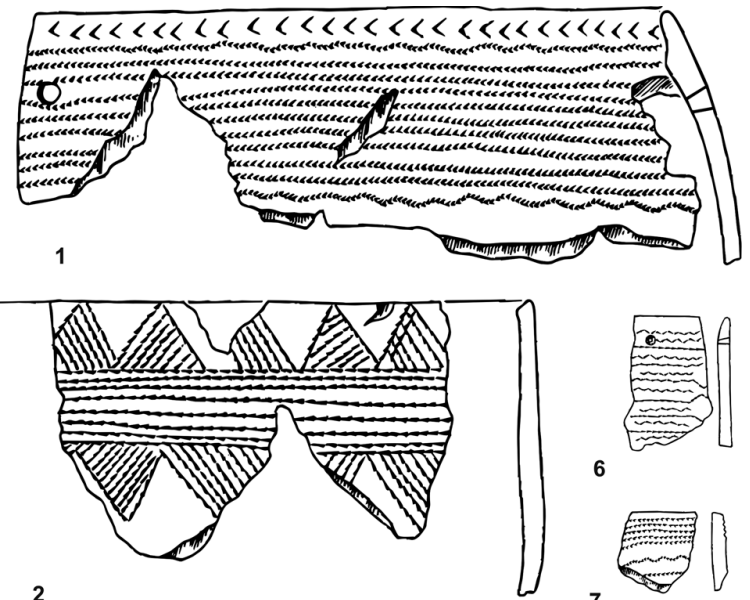
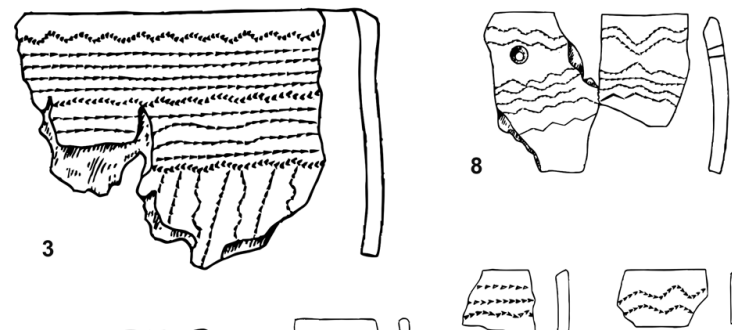

11
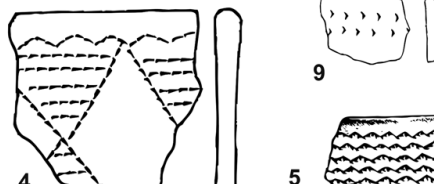

10 9

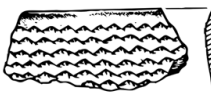

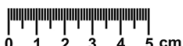

Fig. 5. The North-Western Caspian Sea region. Pottery from the Jangar (1-2 upper layer; 3-5 middle layer; 6-8 lower layer) and Tu-Buzgu-Huduk sites (9-12).

carbonates and organic acids from the soil originating from decomposed organic matter. The $\mathrm{CO}_{2}$ produced from samples is then graphitized before being dated by accelerator mass spectrometry (AMS) at the LMC14 (Cottereau et al. 2007.291-299).

For LSC dating, Zaitseva et al. (2009.796) describe the extraction of carbon for LSC dating of pottery as follows: pottery samples of 200- $400 \mathrm{~g}$ with a carbon content of $1-3 \%$ were taken from vessel walls, and, rarely, from the bottom. The ground samples $(10-22 \mathrm{~mm}$ in diameter) were treated with $0.5 \mathrm{~N}$ hydrofluoric acid in a Teflon ${ }^{\circledR}$ container for 2-5 hours at room temperature. In the initial and final stages, the samples were subjected to 10 minutes of ultrasonic exposure. The samples were then finely ground, dried at under $150-180^{\circ} \mathrm{C}$, and mixed with a calculated amount of manganese dioxide; gaseous products were absorbed by lithium. Lithium carbide was synthesised by vacuum pyrolysis. Benzene was synthesised in a stainless steel reactor under 0.1$2 \mathrm{~atm}$ of pressure. When the temperature rises above $550^{\circ} \mathrm{C}$, the manganese dioxide disintegrates with a uniform release of active oxygen in a wide temperature range of 550 $940^{\circ} \mathrm{C}$. The fine-dyspersated carbon is oxidised, forming carbon oxide and dioxide, which are absorbed by the melted metallic lithium. The lithium carbide is subjected to hydrolysis, and the released acetylene is turned into benzene with a vanadium catalyst (Skripkin, Kovalukh 1998.211-214; Kovalukh, Skripkin 2007.120-126; Zaitseva et al. 2009. 795-801; 2011. 383-385). The benzene cocktails were measured on liquid scintillation counting Quantulus 1220.

In our investigations, the series of radiocarbon dates on pottery carbon from the Early Neolithic sites of Eastern European Russia correlate well with the radiocarbon dates on other organic materials from the
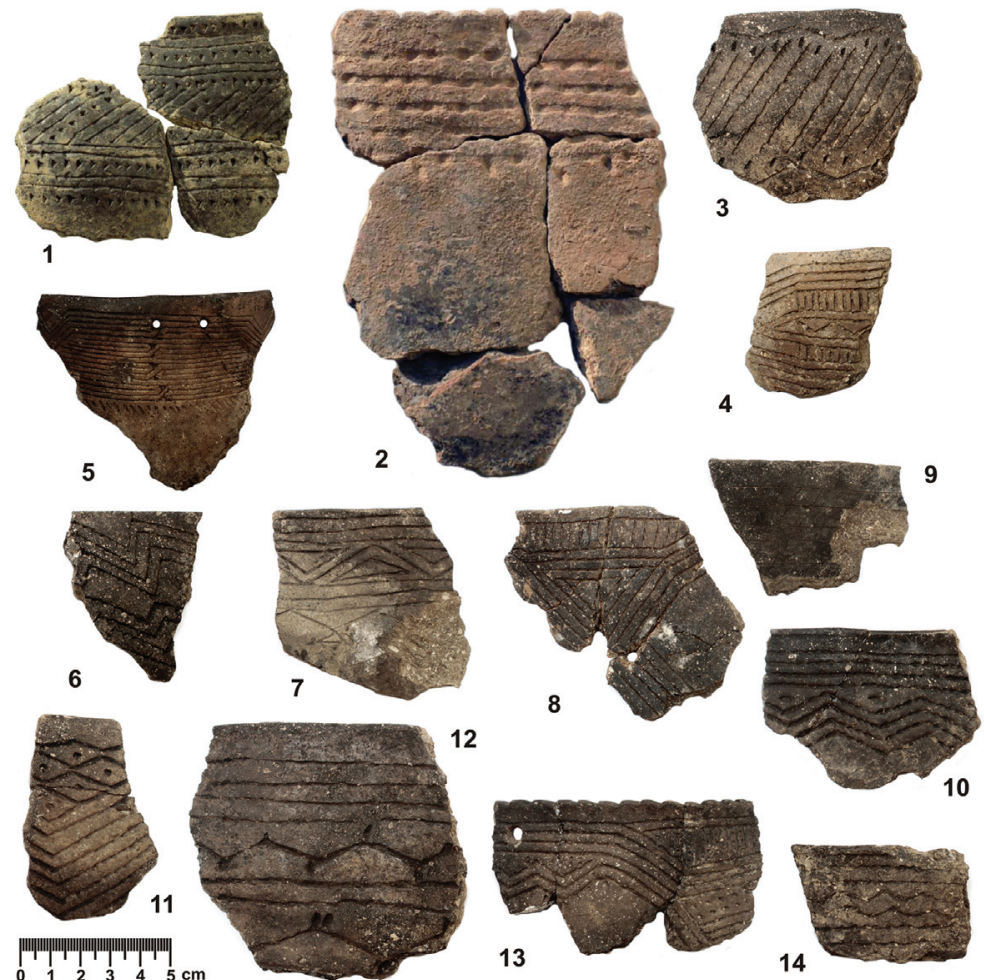

Fig. 6. The Lower Volga region. Pottery from the Algay (1-2) and Varfolomeevskaya sites (3-6 from the upper part (2A) of the middle layer; 7-10 from the lower part (2B) of the middle layer; 11-14 from the lower layer). 
same archaeological settlements and with the existing archaeological periodisation (Vybornov 2008. 490; Vybornov et al. 2012.795-799; 2013.13-20; 2014.242-248; Andreev et al. 2012.193-199; 2016. 155-163; Zaitseva et al. 2009.795-801; 2011.383$385)$. For this reason, these pottery carbon dates were compared to ${ }^{14} \mathrm{C}$ values obtained from charred crusts on the surface of pottery, organics inside vessel's walls, and from bones measured at different laboratories (at the universities of Arizona, St. Petersburg, Uppsala, Poznan, Helsinki, and Aarhus). Similar values were received from these laboratories (Tab. 1). The chronological phases of the different cultures were calculated by means of Bayesian statistics with the help of OxCal 4.2 (Bronk Ramsey 2009.337360) (Figs. 11-15).

\section{Results and discussion}

\section{The Northern Caspian region}

In the last ten years, 70 radiocarbon dates have been obtained for 12 Neolithic sites in the Northern Caspian region. There are 37 dates for organics from pottery, 9 for charred crusts and 5 for charcoal; 9 of these dates were obtained by the AMS technique (Baratskov et al. 2012.200-204; Vybornov et al. 2014.242-248; Andreev et al. 2016a.130-139).

The pottery of Kairshak III type (Fig. 2) from Early Neolithic sites in this region was dated to $6505-$ $5746 \mathrm{cal} \mathrm{BC}$ (Tab. 1.3). Several studies (Kuzmin et al. 2013) have suggested that the geological carbon from clay-silt deposits is the reason for the older dates obtained on the organics from pottery. Kairshak pottery was moulded from an organic silt containing shell. The carbonate fraction from pottery is a radiocarbon dated to 7050-6500 cal $\mathrm{BC}$, while the organics from this pottery date to $6500-5750 \mathrm{cal}$ BC (Tab. 1.5-6). A date of 66906490 cal BC (Tab. 1.1) was obtained on the charred crusts, which can probably be explained by the reservoir effect $(\delta 13 \mathrm{C}=$ $-28.7 \%$ ). This is supported by the date on shell from pottery (Fig. 11). A date of 6230-5890 cal BC (Tab. 1.1-4) was obtained on kulan bones which were found together with pottery. So, the most appropriate age for the Kairshak III cultural tradition is $6500-5750 \mathrm{cal} \mathrm{BC}$.

Late Neolithic period sites also exist in this region. Tenteksor type sites (Fig. 1) are located near to Kairshak. Several radiocarbon dates for these sites have been obtained in different laboratories and on different organic materials. The organics from the Tenteksor type pottery have dates of $5720-5470 \mathrm{cal} \mathrm{BC}$ and 5740-5460 cal BC (Tab. 1.16-17). The radiocarbon date on the charred crusts is $c$. 5680-5530 cal BC (Tab. 1.14). The radiocarbon date on bones is 5640-5310 cal BC (Tab. 1.15). All these dates correlate well between each other. Typologically earlier sites of Tenteksor type have dates from 59005700 cal BC (Vybornov 2008.490). The typology of pottery and the chronological frameworks of surrounding sites did not allow us to accept the younger dates $c .4500 \mathrm{cal} \mathrm{BC}$ (Zaitseva et al. 2009. 795801 ) obtained earlier for the Late Neolithic layers at the Tenteksor site. These dates were obtained on humid acids from soils and on bones calcinated by dia-

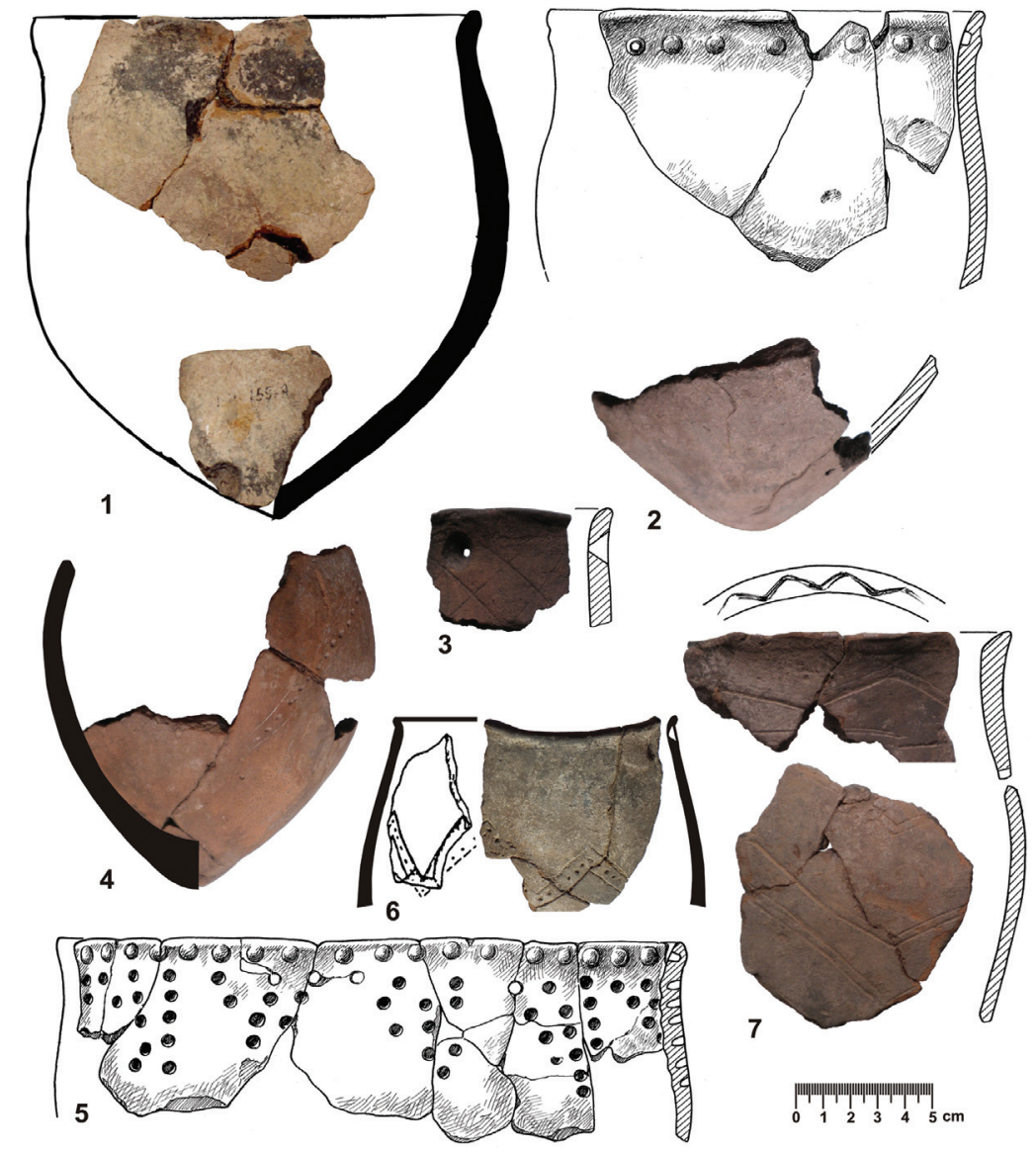

Fig. 7. The forest-steppe of the Volga region. Pottery from the Ivanovskaya (1), Chekalino IV (2, 6-7), B. Rakovka II (3) and Niznaya Orlyanka II (4-5) sites. 
genetic carbonate, and are younger. The date on the shell from pottery is c. $6200 \mathrm{cal} \mathrm{BC}$, and the last date is older than the date on the organics from this sherd (c. $5700 \mathrm{cal} \mathrm{BC}$ ) (Zaitseva et al. 2009.795-801).

Materials from the Baibek site (Grechkina et al. 2014.79-90) complement the chronology of the Early Neolithic of the Northern Caspian region (Fig. $3)$. There are two dates on charred crusts: 7037-6684 and 6373-6070 cal BC (Tab. 1.7, 9). These dates are probably influenced by the reservoir effect, because the date on the bones is $6002-5708 \mathrm{cal} \mathrm{BC}$ (Tab. 1.10) and the dates on charcoal from different laboratories are 5917-5604 and 5983-5759 cal BC (Tab. 1.8, 12). The date on the organics from pottery is 6021-5626 cal BC (Tab. 1.13), which correlates well with dates on bones and food crusts. These results fall into the chronological gap between ages of the Early Neolithic complex of Kairshak type and the Late Neolithic of the Tenteksor sites. Typologically earlier materials from Kairshak III are dated to as early as $6200 \mathrm{cal}$

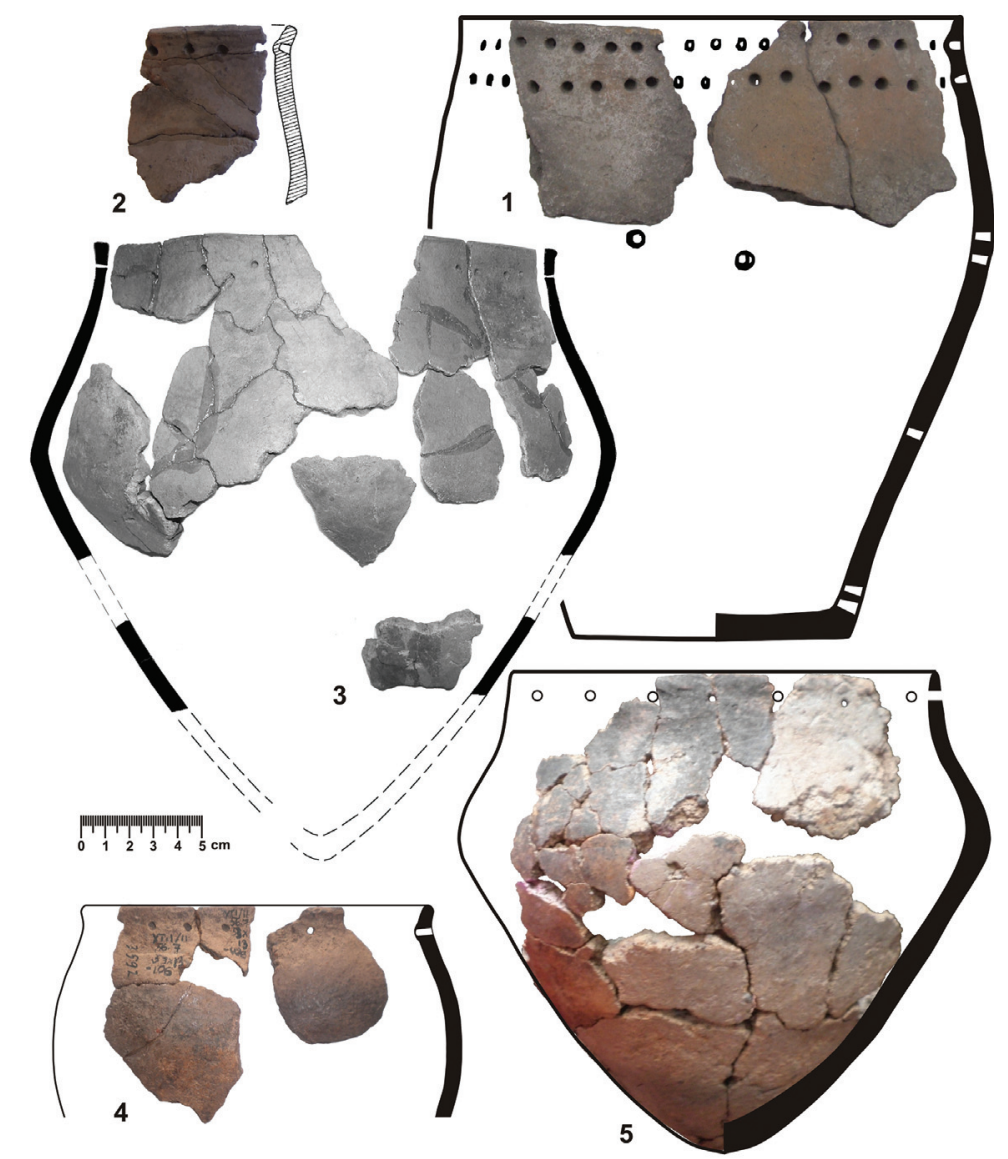

Fig. 8. The forest-steppe of the Volga region (1) and Sura region (2-5). Pottery from the Krasniy Gorodok I (1), Vjunovo lake I (2-3) and Utuzh I (4-5) sites.
BC. The sites at Kugat IV (Fig. 2.1) and Kulgaisi with typologically earlier materials are dated on the basis of organics from pottery to $6600-6220 \mathrm{cal} \mathrm{BC}$ and 6450-6027 cal BC, respectively (Tab. 1.10, 20). The mesolithic characteristics of flint tools found here are good evidence for this earlier chronology ( $\mathrm{Vy}$ bornov 2016.161-166).

Thus, the earliest chronological boundary for the beginning of the Neolithic in the Northern Caspian Sea region will be about $6600 \mathrm{cal} \mathrm{BC}$ and the latest around $5500 \mathrm{cal} \mathrm{BC}$. Until recently, the accepted chronological framework of the Early Neolithic stage for this region was between 5900-4500 BC. The recently excavated archaeological materials and the radiocarbon dates do not support this framework.

Material from the Jangar site (Koltsov 2004) in the north-western Caspian region have also been dated (Fig. 5). The date obtained for organics from pottery in the bottom of layer 3 (Fig. 5.6-8) is 6090-5710 cal BC (Tab. 1.21-22), for upper layer 2 (Fig. 5.3-5) the date is $5840-5510 \mathrm{cal} \mathrm{BC}$ (Tab. 1.25). The date on the charcoal found between these layers is 6010-
5550 cal BC (Tab. 1.23), while the date on charred crusts from pottery in the upper layer (Fig. 5.1-2) is 5575-5470 cal BC (Tab. 1.27).

Thus, the chronological frameworks of the Early Neolithic of the north-western Caspian region are from around 6000-5500 cal BC. Previous research suggested that the Early Neolithic period was about 5500-4900 cal BC (Koltsov 2004). There are typologically earlier archaeological finds, and we can suggest an earlier time from the beginning of the Early Neolithic in the north-western Caspian. The earlier age of artefacts is based on an analysis of the flint tool typology; the flint artefacts are similar to Mesolithic examples, but this material has not been confirmed by radiocarbon dates yet.

\section{The Volga River region}

The steppe region of Low Povolzhye is located in the north of the Caspian region, in the low Volga basin. Until 2007, there were just 7 radiocarbon dates from one site (Varfolomeevskaya); four of these dates contradicted archaeological expectations. The time-frame for the Orlovskaya Neolithic culture in the Low Po- 


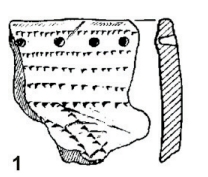

2
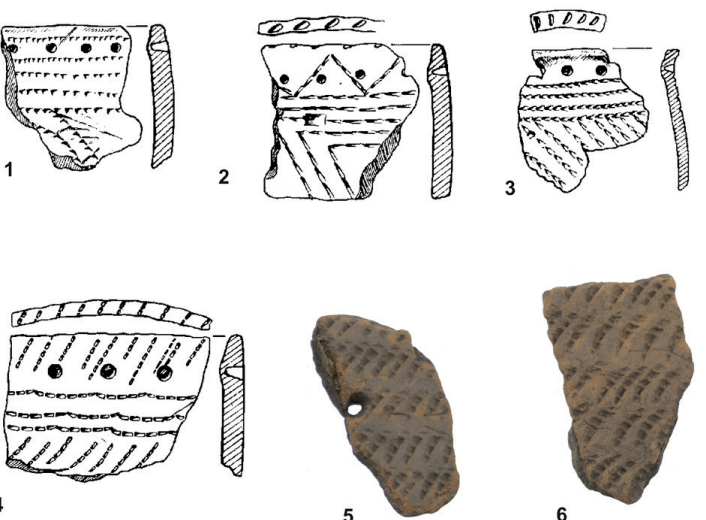

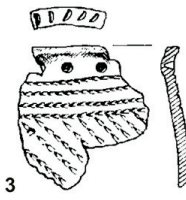

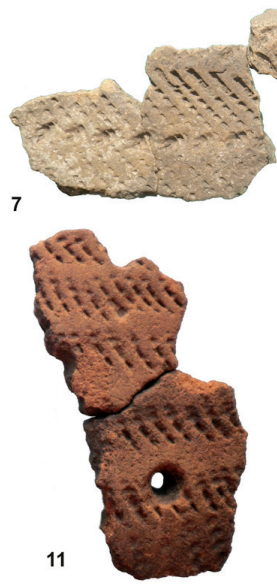
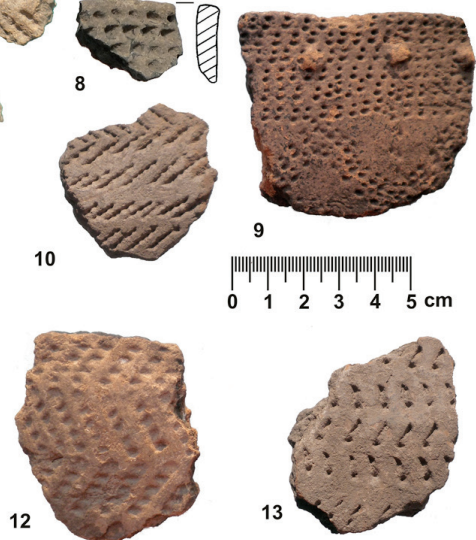

Fig. 9. The forest-steppe of the Volga region. Pottery from the Vilovatovskaya (1-6) and Kalmykovka I (713) sites.

volzhye was estimated to be around 5900-4200 cal $\mathrm{BC}$ (Yudin 2004). In the last ten years, 41 dates have been obtained for this culture: 19 dates on the total organic carbon content of pottery, 12 dates on charred food crusts, 7 dates on bones, and 3 dates on charcoal. Eleven dates were obtained by the AMS technique (Vybornov et al. 2013.13-20; 2014.242248).

The bottom layer (3) of the Varfolomeevskaya site (Fig. 6, 9-14) is dated to 6250-5500 cal BC (Tab. $1.28)$ on charcoal. Almost the same date was obtained on pottery from the same layer, which is 62505980 cal BC (Tab. 1,29). In the bottom layer of the Algay site, the artefacts belonged to the same culture recently found at the Varfolomeevka site (Yudin et al. 2016.61-68). The age of the cultural layer is 62716008 cal BC (Tab. 1.30). These results allow us to determine the beginning of the Low Volga Neolithic to the second half of the $7^{\text {th }}$ millennium.

The middle layer (2B) at the Varfolomeevskaya site (Fig. 6.6-8) was dated earlier, from $c$. 5750-5400 cal BC. Otherwise, the dates on the organics from pottery are from $c$. 6080-6020 cal BC (Vybornov 2008.490). These dates are supported by dates obtained recently on charred crusts $(6220-5740 \mathrm{cal} \mathrm{BC}$ and 6010-5830 cal BC; Tab. 1.31, 32). The upper layer (2A) of this site (Fig. 6.3-5) relates to the period from $c$. 5650-4950 to 5050-4300 cal BC (Tab. 1.3841). The material from the Algay site supports this assumption. The date from charred crusts on pottery from 2B layer at the Varfolomeevskaya site (58165659 cal BC; Tab. 1.33) is close to the date on charred crusts from the lower layer of the Algay site (5741-5631 cal BC; Tab. 1.34) (Fig. 6.1). The dates on the organics from pottery and bones at the Algay site correspond with each other (Tab. 1.34-36). The upper layers of the Varfolomeevskaya and Algay (Fig. 6.2) sites are dated to 5050-4300 and 48564580 cal BC, respectively (Tab. 1.41-43).

These results allow us to determine more precisely the time-frame for each stage of the Orlovskaya culture in this region. The Orlovskaya culture existed from 6000-5500 cal BC, and it coincides with the period of the Early Neolithic in the northern Caspian region. Based on archaeological data, i.e. ceramic typology, researchers supposed the simultaneous de-

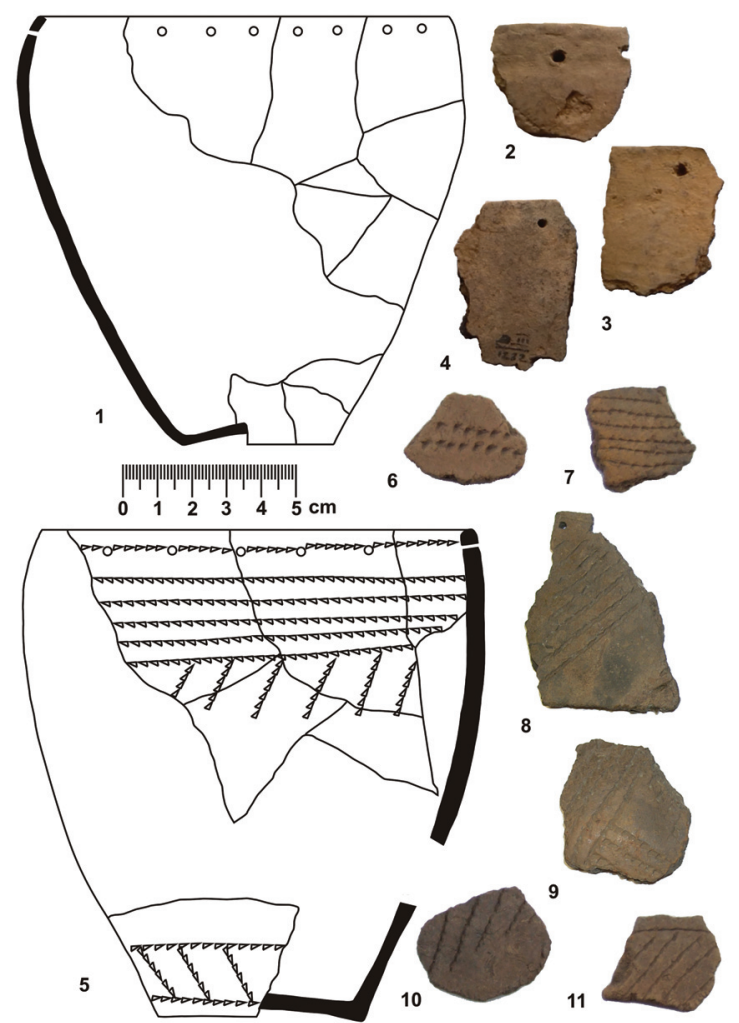

Fig. 10. The forest zone of Volga region. Pottery from the Dubovskaya III (1-5) and II Sherbetskaya (6-11) sites. 


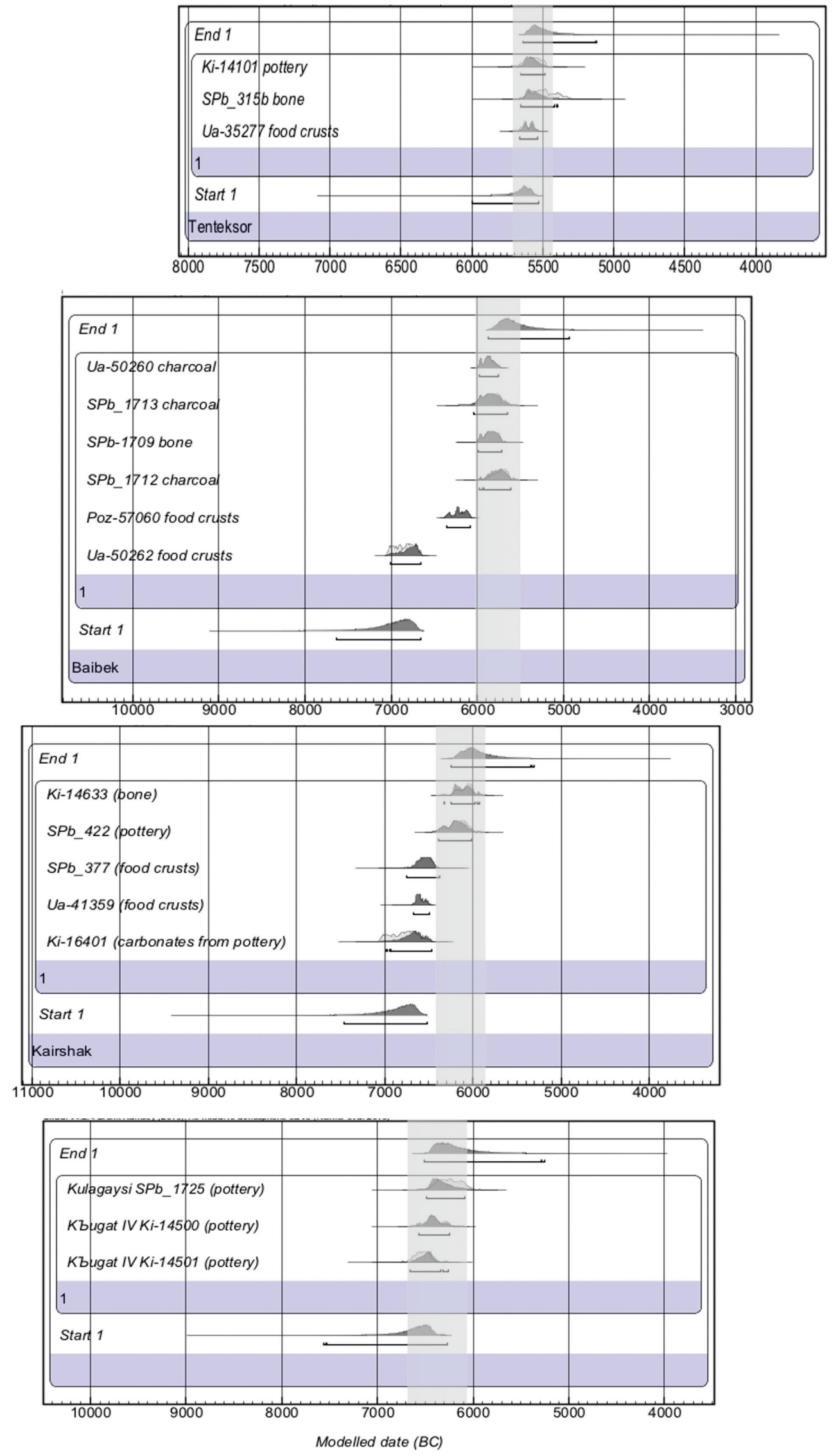

Fig. 11. The distribution of radiocarbon dates (cal BC) for the Early Neolithic cultures of the Northern Caspian Sea region. The grey tone denotes the most appropriate age. 


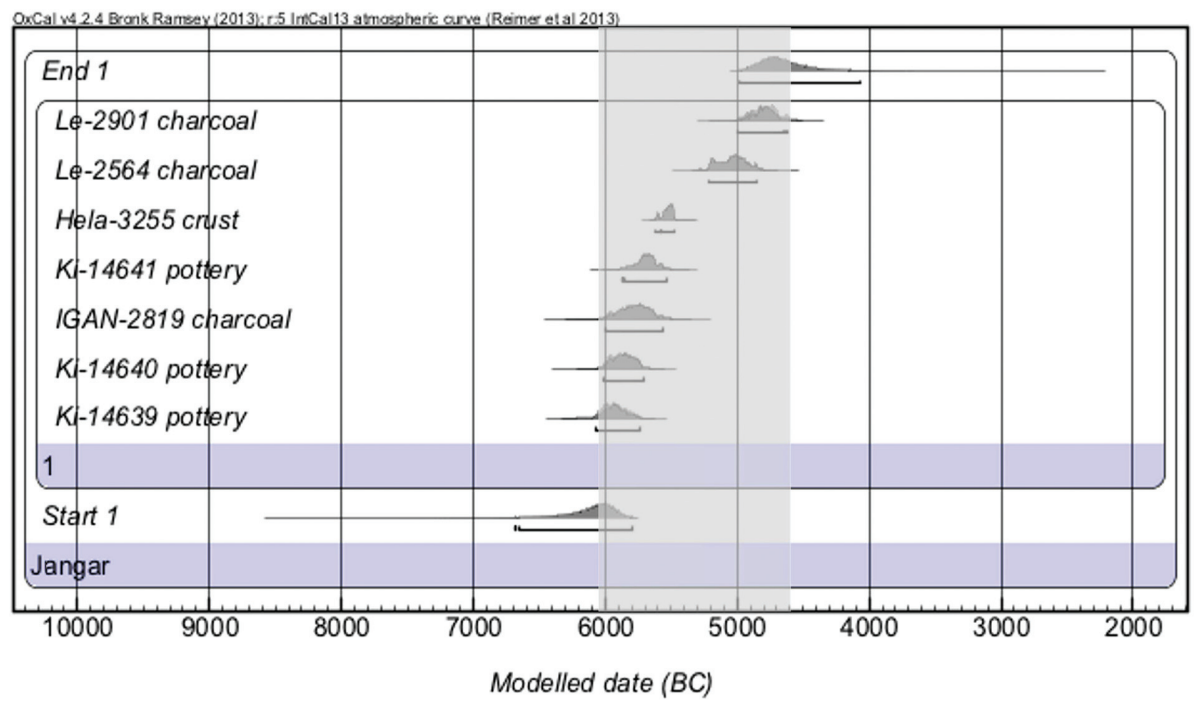

Fig. 12. The distribution of radiocarbon dates (cal BC) for the Jungar culture of the North-Western Caspian Sea region. The grey tone denotes the most appropriate age.

velopment of these cultures in the northern and north-western Caspian region and in the Lower Volga, especially for the last cultural stages. These suggestions were supported recently by new radiocarbon dates. For the eponymous site of the Orlovskaya culture (Orlovka) there is a date of $5846-5315 \mathrm{cal} \mathrm{BC}$ (Tab. 1.37), which correlates well with the dates of late complexes at the the Tenteksor site (Tab. 1.14), from the upper layer of the Jangar site (Tab. 1.27) and from the upper layer (2A) of the Varfolomeevskaya site (Tab. 1.38).

Ten radiocarbon dates were obtained from four Neolithic sites of the forest-steppe Volga region. They were determined in the interval from 7900-7000 cal $\mathrm{BC}$, which is why they were interpreted as the oldest sites in this region. However, nine of them were obtained on shell and could be subject to reservoir effects. Beginning from 2007, 161 dates were obtained from 30 sites of the Elshanian culture in this region. Sixteen dates were obtained by AMS dating. Elshanian culture sites extend from the Ural River to the east to the Moksha River to the west (Fig. 1). The date on the organics from pottery for the most easterly site of the Ivanovskaya site (Fig. $7.1)$ is $6566-6248 \mathrm{cal} \mathrm{BC}$ (Tab. 1.47). For the most westerly, from the Vjunovo Lake site (Fig. 8.2-3) and the Imerka VII site, several dates obtained on the organics from pottery are $c .6220-6004$ and 6092-5927 cal BC according to the AMS technique

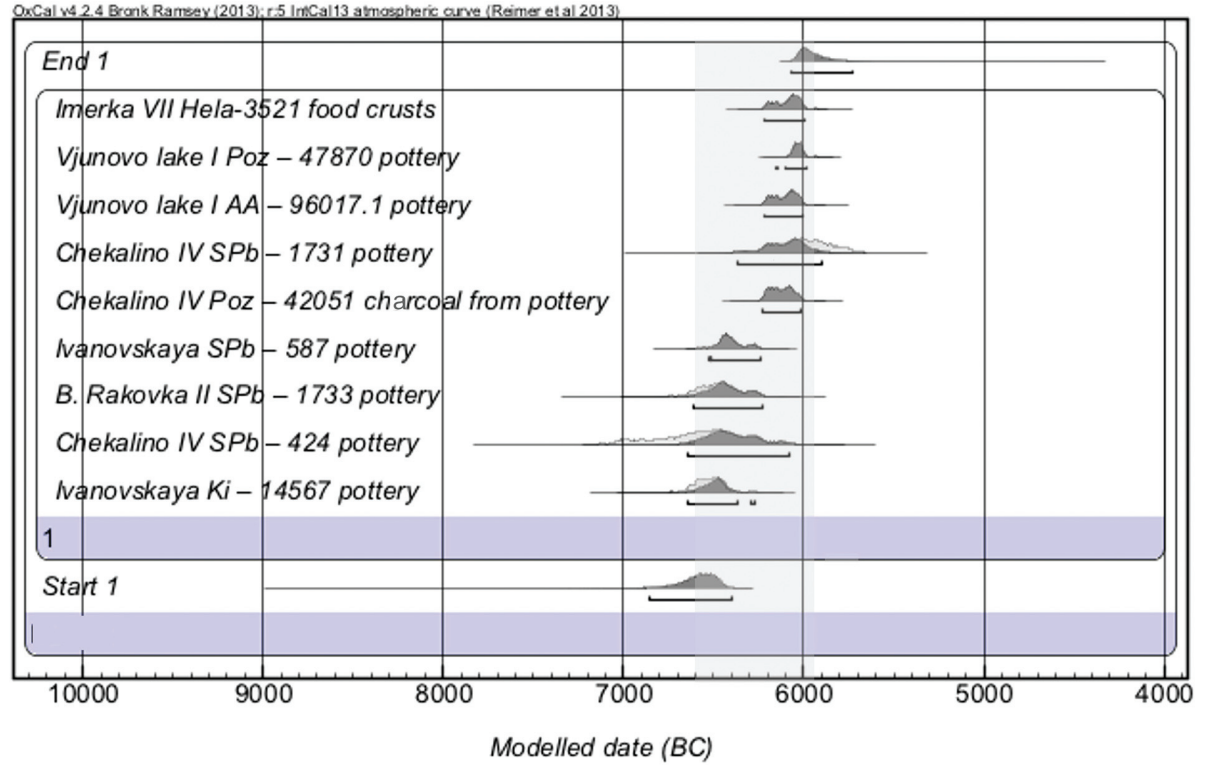

Fig. 13. The distribution of radiocarbon dates (cal BC) for the Early stage of Elshanian culture in the Povolzhye. The grey tone denotes the most appropriate age. 
(the Vjunovo Lake site; Tab. 1.50-51). The date on the charred crusts from the Imerka VII site is 62205980 cal BC (Tab. 1.52). Most of the Elshanian culture sites were excavated in the Samarskoe Povolzhye, in the region of Samara (Fig. 1). The dates on the organics from pottery are 6750-6200 cal BC (Bolshaya Rakovka II site; Fig. 7.3), 7047-6202, and 6400-5700 cal BC (Chekalino IV site; Fig. 7.2,6,7; Tab. 1.46, 45, 49 respectively). Elshanian culture pottery was moulded from clay with organics, without shell inclusions. Therefore, the date on pottery of 7047-6202 cal BC (Tab. 1.45) seems to be older. The most acceptable date for this site is 6229-6016 cal BC (Tab. 1.48), obtained on charcoal from pottery by the AMS technique.

The series of dates for typologically later sites of the Elshanian culture fall into the interval of 6000-5700 cal BC. What is important is that the dates on the organics from pottery correspond with the dates on the charred crusts from the pottery of the same type, taking into account the error of measurement and reservoir effect (5730-5490 and 5740-5370 cal BC, respectively, (Tab. 1.53-54).

The late stage of the Elshanian culture in the Lugovoe III site was dated in the 1980 s to $3500 \mathrm{cal} \mathrm{BC}$ (Vybornov 2008.490). However, these dates contradict archaeological data and the chronology of the forest-steppe Neolithic. At present the series of dates obtained on the material from the late stage, including from the Lugovoe site, are in the interval 57005500 calBC (Vybornov 2008.490). Material of the Elshanian type from the Utuzh I site (Fig. 8.4-5) 1ocated in the basin of the Sura River is dated on the organics from the pottery to $c .5640-5290 \mathrm{cal} \mathrm{BC}$ (Tab. 1.56). The date of 5620-5470 cal BC (Tab. 1.55) on charred crusts from the same fragment of pottery was obtained by the AMS technique.

Thus the chronological period of the spread of Early Neolithic Elshanian culture is from $6500-5500 \mathrm{cal}$ BC.

The Elshanian culture was replaced by the Srednevolzhskaya culture (Vybornov 2008.490) (Fig. 9). On the base of a large series of radiocarbon dates, the period of this culture's development can be determined from 5500-4700 cal BC (Tab. 1.59-63). There is a good correlation between dates obtained on the organics from pottery and bones (Tab. 1.64- 65).

In the southern steppe region of Povolzhye, the Early Neolithic period is dated between 6500-6000 cal BC and the Late Neolithic period between $6000-5500$ cal BC. In the forest-steppe zone, the Early Neolithic is dated between $6500-5500$ cal $\mathrm{BC}$, but the Late Neolithic lasted from 5500-4700 cal BC.

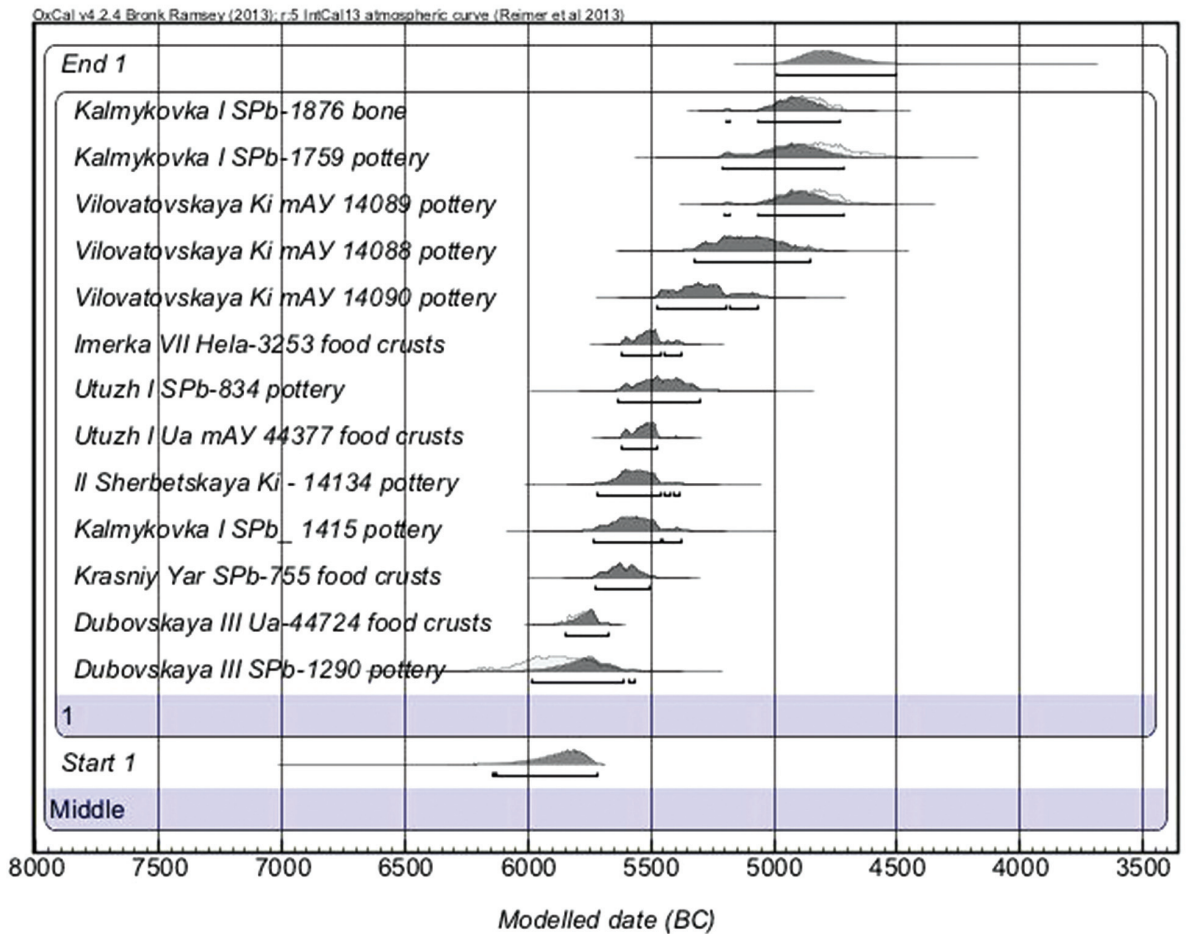

Fig. 14. The distribution of radiocarbon dates (cal BC) for the Late stage of Srednevolzhskaya culture in the Povolzhye. The grey tone denotes the most appropriate age.
In the forest zone of the Middle Volga region the Early Neolithic has been dated to c. 5000 cal BC. At present, there are the 24 dates from the 8 sites. Typologically the earliest pottery from the Dubovskaya III site (Fig. 10.1-4) has the date of $5925 \pm 325 \mathrm{cal}$ BC (Tab. 1.57). The charred crusts from this fragment of pottery date to $5795 \pm 95$ cal BC (Tab. 1.58). Pottery actually appeared in the forest zone of the Middle Volga region 1000 years earlier than it was thought to have done several years ago, and this pro- 


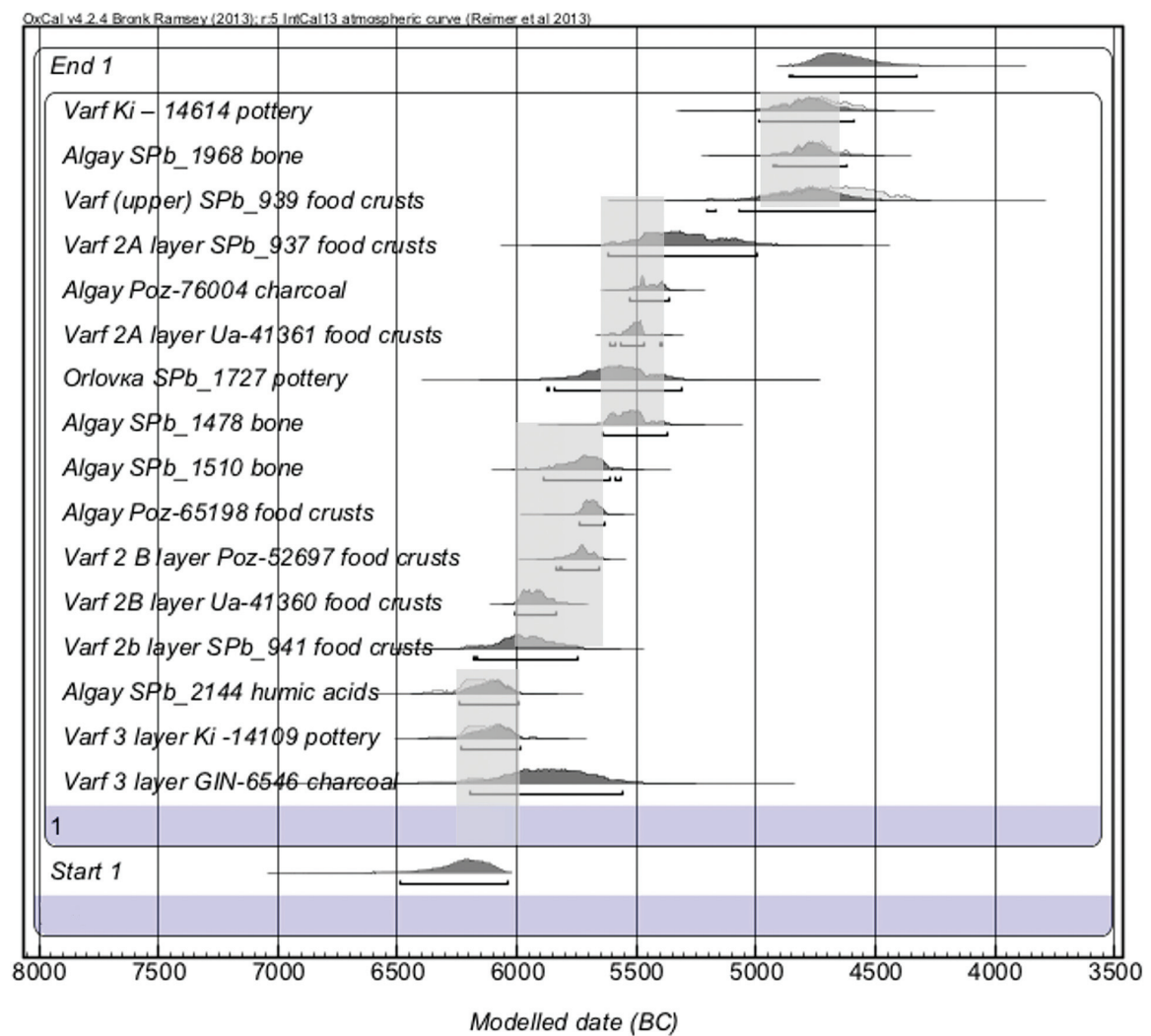

Fig. 15. The distribution of radiocarbon dates (cal BC) for the Orlovskaya culture in the Lower Povolzhye. The grey tone denotes the most appropriate age.

cess occurred 200-500 years later than in the southern forest-steppe zone.

\section{Conclusion}

An array of radiocarbon dates on different organic material from almost all the Povolzhye Neolithic sites has been obtained in the last 10 years. The analysis of these dates has shown a good correlation between most of the dates on the charcoal, food crusts, bone, and organics from ceramics from different sites. The correlation of these radiocarbon dates with stratigraphic successions of cultural layers at the sites and the pottery typology allow us to correct the chrono- logical frameworks of the Neolithic in the Low and Middle Povolzhye region. This schema differs from the schema accepted until 2007. The chronological frameworks of the Neolithic in the steppe Povolzhye date from $6500-5500 \mathrm{cal} \mathrm{BC}$, In the forest-steppe zone of Middle Povolzhye, the Neolithic period is dated from $6500-4700 \mathrm{cal} \mathrm{BC}$, and in the forest zone of the Middle Povolzhye, the Neolithic period lasted from 6000-4300 cal BC.

\section{ACKNOWLEDGEMENTS}

This article was supported by project 33.1907.2017 of the Russian Ministry of Education and Science.

\section{References}

Anderson A., Chappel J., Clark G. and Phear S. 2005. Comparative radiocarbon dating of lignite, pottery, and charcoal samples Babeldaob Island, Republic of Palau. Radiocarbon 47(1): 1-9.

Andreev K. M., Vybornov A. A. and Kulkova M. A. 2012. Nekotorye itogi i perspectivy datirovaniya elshanskoi kultury lesostepnogo Povolzhya [Some results and perspec- tives of dating the Elshanka Culture in forest steppe Volga River region]. Izvestiya Samarskogo nauchnogo tsentra Rossiyskoy akademii nauk 14(3): 193-199. (in Russian)

Andreev K. M. 2015. Ranniy neolit lesostepnogo Povol$z h ' y a$. Avtoreferat diss. kand. ist. nauk. Sankt-Peterburg. (in Russian) 
Andreev K. M., Baratskov A. V., Vybornov A. A., Kul'kova M. A., Oinonen M., Possnert G., Meadows J., van der Plicht J. and Philippsen B. 2016. [New radiocarbon dates of Neolithic and Eneolithic sites of Povolzhye and Podonye] Novye radiouglerodnye daty neoliticheskikh i eneoliticheskikh pamyatnikov Povolzh'ya i Podon'ya. Izvestiya Samarskogo nauchnogo tsentra Rossiyskoy akademii nauk 18(6): 170-177. (in Russian)

Andreev K. M., Vybornov A. A., Vasil'yeva I. N. and Somov A. V. 2016a. Novye neoliticheskiye materialy stoyanki Kalmykovka I [New Neolithic materials of Kairshak site]. Izvestiya Samarskogo nauchnogo tsentra Rossiyskoy akademii nauk 18(3): 130-139. (in Russian)

Baratskov A. V., Vybornov A. A. and Kulkova M. A. 2012. Problemy absolutnoi khronologii neolita Severnogo Prikaspiya [Problems in absolute dating of the Neolithic in Northern Caspian region]. Izvestiya Samarskogo nauchnogo tsentra Rossiyskoy akademii nauk 14(3): 200-204. (in Russian)

Brunet F., Khudhzanazarov M. and Hoshimov H. 2012. Nouvelles données sur la chronologie de la culture de Kel'teminar (VIIe-IVe millénaires) en Ouzbékistan. In A. Berdimuradov (ed.), Istorija Material'noj Kul'tury Uzbekistana (The History of Material Culture of Uzbekistan). Institute of archaeology of the Academy of Sciences of Uzbekistan. Samarkand: 118-124.

Bronk Ramsey C. 2009. Bayesian analysis of radiocarbon dates. Radiocarbon 51(1): 337-360.

Boudin M., Strydonck M. V., Crombé P., Clercq W. D., Dierendonck R. M., Jongepier H., Ervynck A. and Lentacker A. 2010. Fish reservoir effect on charred food residue ${ }^{14} \mathrm{C}$ dates: are stable isotope analyses the solution? Radiocarbon 52(2-3): 697-705.

Bonsall C., Cook G., Manson J. L. and Sanderson D. 2002. Direct dating of Neolithic pottery: progress and prospects. Documenta Praehistorica 29: 47-59.

Cottereau E., Arnold M., Moreau C., Baqué D., Bavay D., Caffy I., Comby C., Dumoulin J.-P., Hain S., Perron M., Salomon J. and Setti V. 2007. Artemis, the new ${ }^{14 C}$ AMS at LMC14 in Saclay, France. Radiocarbon 49(2): 291-299.

Delquè Kolic E. 1995. Radiocarbon dating of pottery: selective heat treatment to retrieve smoke-derived carbon. Radiocarbon 37(2): 275-284.

Evin J., Gabasio M. and Lefevre J.-C. 1989. Preparative techniques for radiocarbon dating of potsherds. Radiocarbon 31(3): 276.
Fischer A., Heinemeier J. 2003. Freshwater reservoir effect in ${ }^{14} \mathrm{C}$ dates of food residue on pottery. Radiocarbon 45 (3): $449-466$.

Grechkina T. Y., Vybornov A. A. and Kutukov D. V. 2014. Novaya ranneneoliticheskaya stoyanka Baybek v Severnom Prikaspii [New Early Neolithic site Baibek in the Northern Caspian Sea region]. Samarskiy nauchnyy vestnik 3: 79-90. (in Russian).

Hart J. P., Lovis W. A., Urquhart G. R. and Reber E. A. 2013. Modeling Freshwater Reservoir Offsets on RadiocarbonDated Charred Cooking Residues. American Antiquity 78(3): 536-552.

Hedges R. E. M., Tiemei Ch. and Housley R. A. 1992. Results and methods in the radiocarbon dating of pottery. Radiocarbon 34(3): 906-915.

Kholmatova Z. N. 2012. The ceramics of Kaltaminor (from variants of variants of the local cultures). In A. Berdimuradov (ed.), Istorija Material'noj Kul'tury Uzbekistana (The History of Material Culture of Uzbekistan). Institute of archaeology of the Academy of Sciences of Uzbekistan. Samarkand: 106-110.

Koltsov P. M. 2004. Poseleniye Jangar. Moskva. (in Russian)

2005. Mezolit i Neolit Severo-Zapadnogo Prikaspiya [The Mesolithic and Neolithic of the Northwestern Caspian Region]. Moskva. (In Russian)

Kovaklukh N. N., Skripkin V. V. 2007. Radiouglerodnoe datirovanie arkheologicheskoi keramiki zhidkostnostsintillatsionnym metodom [The radiocarbon dating of archaeological pottery by liquid scintillation method]. Radiouglerod v Arkheologicheskikh i Paleoekologicheskikh Issledovaniyakh. Sankt-Peterburg: 120-126. (in Russian)

Kozin E. V. 2002. Neolit Severnogo Prikaspiya. Avtoref. kand. diss. ist. nauk. Izhevsk: 1-16 (in Russian)

Kul'kova M. A. 2014. Radiouglerodnoye datirovaniye drevney keramiki. Samarskiy nauchnyy vestnik 3: 115-122. (in Russian)

Kunikita D., Shevkomud I., Yoshida K., Onuki Sh., Yamahara T. and Matsuzaki H. 2013. Dating charred remains of pottery and analyzing food habits in the Early Neolithic period in Northeast Asia. Radiocarbon 55(2-3): $1334-1340$.

Kuzmin Y. V., Hall S., Tite M. S., Bailey R., O'Malley J. M. and Medvedev V. E. 2001. Radiocarbon and thermoluminescence dating of the pottery from the early Neolithic site 
of Gasya (Russian Far East): initial results. Quaternary Science Reviews 20: 945-948.

Mamonov A. E. 2000. Elshanskaya kultura [The Elshanka Culture]. In P. S. Kabytov (ed.), Istoriya Samarskogo Povolzhya s Drevneishikh Vremen to Nashikh Dnei. Samara: 147-176. (in Russian)

Messili L., Saliège J. F., Broutin J., Messager E., Hatté Ch. and Zazzo A. 2013. Direct ${ }^{14} \mathrm{C}$ dating of early and Mid-Holocene Saharan pottery. Radiocarbon 55(2-3): 13911402.

Morgunova N. L. 2004. K problem opredeneniya kulturnoi prnadlezhnosti i khronologii neoliticheskikh pamyatnikov Samarskogo Povolzhya i Yuzhnogo Zauralya [To the problem of determination of cultural affiliation and chronology of the Neolithic sites in the Samara region of Volga Basin and the southern Trans-Urals]. In Problemy Khronologii i Etnokulturnykh Vzaimodeistvyi v Neolite Evrazii. Sankt-Peterburg: 214-216. (in Russian)

Nakamura T., Taniguchi Y., Tsuji S. and Oda H. 2001. Radiocarbon dating of charred residues on the earliest pottery in Japan. Radiocarbon 43(2B): 1129-1138.

O'Malley J. M., Kuzmin Y. V., Burr G. S., Donahue D. J. and Jull A. J. T. 1999. Direct radiocarbon accelerator mass spectrometric dating of the earliest pottery from the Russian Far East and Transbaikal. Memoires de la Societe prehistorique francaise XXVI: 19-24.

Philippsen B. 2013.The freshwater reservoire effect in radiocarbon dating. Heritage Science 1: 24.

Skripkin V. V., Kovalyukh N. N. 1998. Recent developments in the procedures used at the SSCER laboratory for the routine preparation of lithium carbide. Radiocarbon 40(1): 211-214.

Stott A. W., Berstan R., Evershed P., Hedges R. E. M., Bronk Ramsey C. and Humm M. J. 2001. Radiocarbon dating of single compounds isolated from pottery cooking vessel residues. Radiocarbon 43(2A): 191-197.

Vybornov A. A. 2008. Neolit Volgo-Kamya [The Neolithic of the Volga-Kama Region]. Samara State University. Samara: 490. (in Russian)

2016. Initial stages of two Neolithisation models in the Lower Volga basin. Documenta Praehistorica 43: 161166.

Vybornov A., Dolukhanov P., Aleksandrovsky A., Kovaliukh N., Skripkin V., Sapelko T., Zaytseva G. and Shuku- rov A. 2009a. The Middle Volga Neolithic. In P. Dolukhanov, G. R. Sarson and A. M. Shukurov (eds.), The East European Plain on of Eve of Agriculture. British Archaeological Reports IS 1964. Archaeopress. Oxford: 71-80.

Vybornov A., Dolukhanov P., Kovalyukh N., Skripkin V., Zaitseva G. and Shukurov A. 2009b. The North Caspian Mesolithic and Neolithic. In P. Dolukhanov, G. R. Sarson and A. M. Shukurov (eds.), The East European Plain on of Eve of Agriculture. British Archaeological Reports IS 1964. Archaeopress. Oxford: 81-88.

Vybornov A., Zaitseva G., Kovaliukh N., Kulkova M., Possnert G. and Skripkin V. 2012. Chronological problems with Neolithization of the Northern Caspian Sea Area and the forest-steppe Povolzhye Region. Radiocarbon 54 (3-4): 795-799.

Vybornov A., Kulkova M., Goslar T. and Possnert G. 2013. The problem of the neolithisation process chronology in Povolzhye. Documenta Praehistorica 40: 13-20.

Vybornov A. A., Andreyev K. M., Baratskov A. V., Grechkina T. Y., Lychagina Y. L., Naumov A. G., Zaytseva G. I., Kul'kova M. A., Goslar T., Oynonen M. and Possnert G. 2014. Novyye radiouglerodnyye dannyye dlya materialov neolita-eneolitaVolgo-Kam'ya.[New radiocarbon data for materials of Neolithic-Eneolithic of Volgo-Kama region]. Izvestiya Samarskogo nauchnogo tsentra Rossiyskoy akademii nauk 16(4): 242-248. (in Russian)

Yudin A. I. 2004. Varfolomeevskaya stoyanka i neolit stepnogo Povolzhya. Saratov. (in Russian)

Yudin A. I., Vybornov A. A., Vasil'yeva I. N., Kosintsev P. A., Kul'kova M. A., Goslar T., Philippsen B. and Baratskov A. V. 2016. Neoliticheskaya stoyanka Algay v Nizhnem Povolzh'ye [Neolithic site Algay in the Low Povolzhye region]. Samarskiy nauchnyy vestnik 3(16): 61-68. (in Russian)

Zaitseva G. I., Skakovsky E. D., Possnert G., Vybornov A. A., Kovalukh N. N. and Skripkin V. V. 2011. Organicheskoe veshchestvo keramiki: priroda, organicheskie komponenty i dostovernost radiouglerodnykh dat [The organic matter in pottery: the origin, organic components, and the reliability of radiocarbon dates]. Trudy III-go Vserossiiskogo Arkheologicheskogo Syezda. Tom 2. SanktPeterburg-Moskva-Veliky Novgorod: 383-385. (in Russian)

Zaitseva G., Skripkin V., Kovalyukh N., Possnert G., Dolukhanov P. and Vybornov A. 2009. Radiocarbon dating of Neolithic pottery. Radiocarbon 51(2): 795-801. 